Supplement of Biogeosciences, 11, 2477-2501, 2014

http://www.biogeosciences.net/bg-11-2477-2014/

doi:10.5194/bg-11-2477-2014-supplement

(C) Author(s) 2014. CC Attribution 3.0 License.

(c) (i)

Supplement of

\title{
Phytoplankton primary production in the world's estuarine-coastal ecosys-
} tems

\section{J. E. Cloern et al.}

Correspondence to: J. E. Cloern (jecloern@usgs.gov) 
Supplementary material for manuscript entitled: Review: Phytoplankton Primary Production in the World's Estuarine-Coastal Ecosystems

Authors: James E. Cloern, Sarah Q. Foster, Amy E. Kleckner

Table S1. Inventory of median annual phytoplankton primary production (APPP) computed from 1148 measurements made in 131 estuarine-coastal ecosystems. Forty-seven of these values are single measurements made at one site during one year; the others represent the medians of measurements made at multiple sites and/or during multiple years (see Fig. 5 and text for details). GPP = gross primary production; NPP = net primary production; $\mathrm{U}=$ unreported; $\mathrm{n}=$ number of annual measurements made for each region and measurement type.

\begin{tabular}{|c|c|c|c|c|c|c|c|}
\hline Ecosystem & Country & Region & Measure & Method & $\begin{array}{c}\text { Median } \\
\text { APPP } \\
\mathrm{g} \mathrm{C} \mathrm{m}^{-2} \mathrm{yr}^{-1}\end{array}$ & $\mathbf{n}$ & Reference \\
\hline$\emptyset$ resund & DENMARK/ SWEDEN & Baltic & GPP & $14 \mathrm{C}$ & 39 & 1 & (Steeman Nielsen, 1958) \\
\hline$\varnothing$ resund & DENMARK/ SWEDEN & Baltic & U & $14 \mathrm{C}$ & 130 & 37 & (Rydberg et al., 2006; /Ertebjerg et al., 1981) \\
\hline Aarhus Bay & DENMARK & Europe & GPP & $14 \mathrm{C}$ & 437 & 1 & (Jørgensen, 1996) \\
\hline Aarhus Bay & DENMARK & Europe & NPP & $14 \mathrm{C}$ & 260 & 1 & (Jørgensen, 1996) \\
\hline Adriatic Sea coastal & ITALY & Europe & U & $14 \mathrm{C}$ & 208 & 3 & (Zoppini et al., 1995) \\
\hline Adyar Estuary & INDIA & Asia & GPP & $\mathrm{O} 2$ & 83 & 1 & (Purvaja and Ramesh, 2000) \\
\hline Akkeshi Bay & JAPAN & Asia & GPP & $14 \mathrm{C}$ & 416 & 1 & (Taguchi et al., 1977) \\
\hline Akkeshi Bay & JAPAN & Asia & NPP & $14 \mathrm{C}$ & 146 & 1 & (Taguchi et al., 1977) \\
\hline Altamaha River Mouth & USA & North America & U & $14 \mathrm{C}$ & 546 & 1 & (Thomas, 1966) \\
\hline Apalachicola Bay & USA & North America & $U$ & $14 \mathrm{C}$ & 261 & 3 & (Mortazavi et al., 2000) \\
\hline Arcachon Bay & FRANCE & Europe & $\mathrm{U}$ & $14 \mathrm{C}$ & 103 & 1 & (Glé et al., 2008) \\
\hline Arkona Basin & DENMARK/ SWEDEN & Baltic & $u$ & $14 \mathrm{C}$ & 131 & 8 & (ÆErtebjerg et al., 1981) \\
\hline Balsforden & NORWAY & Europe & $\mathrm{U}$ & $14 \mathrm{C}$ & 110 & 3 & (Eilertsen and Taasen, 1984) \\
\hline Baltic Sea & FINLAND/SWEDEN & Baltic & $U$ & $14 \mathrm{C}$ & 57 & 1 & (Fonselius, 1972) \\
\hline Barataria Bay & USA & North America & GPP & $\mathrm{O} 2$ & 300 & 1 & (Brkich, 1972) cited in (Day et al., 1973) \\
\hline Barataria Bay & USA & North America & NPP & 02 & 210 & 1 & (Brkich, 1972) cited in (Day et al., 1973) \\
\hline Barra de Navidad & MEXICO & South-Central America & GPP & $\mathrm{O} 2$ & 324 & 1 & (Sandoval-Rojo, 1988) \\
\hline Barra de Navidad & MEXICO & South-Central America & NPP & $\mathrm{O} 2$ & 242 & 1 & (Sandoval-Rojo, 1988) \\
\hline Bay of Brest & FRANCE & Europe & $U$ & $14 \mathrm{C}$ & 148 & 1 & $\begin{array}{l}\text { (Del Amo et al., 1997); Y. Del Amo, pers. comm. } \\
\text { 03/29/2011 }\end{array}$ \\
\hline Bedford Basin & CANADA & North America & $\mathrm{U}$ & $14 \mathrm{C}$ & 213 & 1 & (Platt, 1975) \\
\hline
\end{tabular}




\begin{tabular}{|c|c|c|c|c|c|c|c|}
\hline Biscayne Bay & USA & North America & $\mathrm{U}$ & $14 \mathrm{C}$ & 22 & 4 & (Roman et al., 1983) \\
\hline Bissel Cove & USA & North America & GPP & $\mathrm{O} 2$ & 121 & 1 & (Nixon and Oviatt, 1973) cited in (Welsh et al., 1982) \\
\hline Bissel Cove & USA & North America & NPP & $\mathrm{O} 2$ & 56 & 1 & (Nixon and Oviatt, 1973) cited in (Welsh et al., 1982) \\
\hline Boston Harbor & USA & North America & $\mathrm{U}$ & $14 \mathrm{C}$ & 494 & 11 & (Oviatt et al., 2007) \\
\hline Bristol Channel & UNITED KINGDOM & Europe & $\mathrm{U}$ & $14 \mathrm{C}$ & 49 & 3 & (Joint and Pomroy, 1981) \\
\hline Burrard Inlet & CANADA & North America & $\mathrm{U}$ & $14 \mathrm{C}$ & 358 & 10 & (Stockner et al., 1979) \\
\hline Cananéia Lagoon & BRAZIL & South-Central America & $\mathrm{U}$ & $14 \mathrm{C}$ & 125 & 1 & (Tundisi, 1973) \\
\hline Charlestown-Green Hill Pond & USA & North America & $\mathrm{U}$ & $14 \mathrm{C}$ & 32 & 1 & (Nixon and Lee, 1981) cited in (Nixon, 1982) \\
\hline Chesapeake Bay 1960s & USA & North America & GPP & $\mathrm{O} 2$ & 90 & 24 & (Flemer, 1970) \\
\hline Chesapeake Bay & USA & North America & GPP & $14 \mathrm{C}$ & 456 & 8 & (Harding et al., 2002) \\
\hline Chesapeake Bay & USA & North America & NPP & $14 \mathrm{C}$ & 423 & 11 & (Harding et al., 2002) \\
\hline Chesapeake Bay & USA & North America & $\mathrm{U}$ & $14 \mathrm{C}$ & 501 & 6 & (Boynton, 1982) \\
\hline Chincoteague Bay & USA & North America & GPP & $\mathrm{O} 2$ & 431 & 3 & (Boynton, 1973) \\
\hline Chincoteague Bay & USA & North America & NPP & $\mathrm{O} 2$ & 178 & 3 & (Boynton, 1973) \\
\hline $\begin{array}{l}\text { Ciénaga Grande de Santa } \\
\text { Marta }\end{array}$ & COLOMBIA & South-Central America & NPP & $\mathrm{O} 2$ & 990 & 1 & (Hernandez and Gocke, 1990) \\
\hline $\begin{array}{l}\text { Ciénaga Grande de Santa } \\
\text { Marta }\end{array}$ & COLOMBIA & South-Central America & GPP & $\mathrm{O} 2$ & 1690 & 1 & (Hernandez and Gocke, 1990) \\
\hline Cochin Backwater & INDIA & Asia & GPP & $\mathrm{O} 2$ & 280 & 1 & (Qasim, 1970) \\
\hline Cochin Backwater & INDIA & Asia & NPP & $14 \mathrm{C}$ & 124 & 1 & (Qasim, 1970) \\
\hline Colne Estuary & UNITED KINGDOM & Europe & GPP & $14 \mathrm{C}$ & 5 & 4 & (Kocum et al., 2002) \\
\hline Columbia River Estuary & USA & North America & NPP & $14 \mathrm{C}$ & 50 & 9 & (Anderson, 1964; Small et al., 1990; Lara-Lara et al., 1990) \\
\hline Core-Bogue Estuarine System & USA & North America & GPP & $\mathrm{O} 2$ & 99 & 31 & (Williams, 1966; Williams and Murdoch, 1966) \\
\hline Core-Bogue Estuarine System & USA & North America & NPP & $\mathrm{O} 2$ & 45 & 31 & (Williams, 1966; Williams and Murdoch, 1966) \\
\hline Core-Bogue Estuarine System & USA & North America & $U$ & $14 \mathrm{C}$ & 104 & 12 & $\begin{array}{l}\text { (Fisher et al., 1982; Sanders and Kuenzler, 1979; Thayer, } \\
1969,1971 \text { ) }\end{array}$ \\
\hline Dabob Bay & USA & North America & $\mathrm{U}$ & $14 \mathrm{C}$ & 194 & 1 & (Welschmeyer and Lorenzen, 1985) \\
\hline Delaware Bay & USA & North America & NPP & $14 \mathrm{C}$ & 175 & 8 & (Pennock and Sharp, 1986) \\
\hline Dokai Bay & JAPAN & Asia & $\mathrm{U}$ & $13 \mathrm{C}$ & 180 & 1 & (Tada et al., 2001) \\
\hline Douro Estuary & PORTUGAL & Europe & NPP & $14 \mathrm{C}$ & 106 & 3 & (Azevedo et al., 2006) \\
\hline Dumbell Bay & CANADA & North America & GPP & $\mathrm{O} 2$ & 12 & 1 & (Apollonio, 1980) \\
\hline Dumbell Bay & CANADA & North America & NPP & $14 \mathrm{C}$ & 9 & 1 & (Apollonio, 1980) \\
\hline Duplin River Estuary & USA & North America & GPP & $\mathrm{O} 2$ & 231 & 3 & (Ragotzkie, 1959) \\
\hline
\end{tabular}




\begin{tabular}{|c|c|c|c|c|c|c|c|}
\hline Dutch Wadden Sea & NETHERLANDS & Europe & GPP & $\mathrm{O} 2$ & 146 & 1 & (Loebl et al., 2007) \\
\hline Dutch Wadden Sea & NETHERLANDS & Europe & $\mathrm{U}$ & $14 \mathrm{C}$ & 213 & 10 & (Cadée and Hegeman, 1979, 1993; Philippart et al., 2007) \\
\hline Dybs $\varnothing$ Fjord & DENMARK & Baltic & GPP & $14 \mathrm{C}$ & 6 & 2 & (Steeman Nielsen, 1957, 1958) \\
\hline El Verde Lagoon & MEXICO & South-Central America & NPP & $\mathrm{O} 2$ & 521 & 1 & (Flores-Verdugo et al., 1988) \\
\hline Ems-Dollard Estuary & $\begin{array}{l}\text { GERMANY/ } \\
\text { NETHERLANDS }\end{array}$ & Europe & $\mathrm{U}$ & $14 \mathrm{C}$ & 136 & 33 & (Colijn and Ludden, 1983) \\
\hline Ennore Creek & INDIA & Asia & GPP & 02 & 157 & 1 & (Purvaja and Ramesh, 2000) \\
\hline Estero de Morales & COSTA RICA & South-Central America & GPP & $\mathrm{O} 2$ & 457 & 1 & (Gocke et al., 2001b) \\
\hline Estero de Morales & COSTA RICA & South-Central America & NPP & $\mathrm{O} 2$ & 278 & 1 & (Gocke et al., 2001b) \\
\hline Estero Pargo & MEXICO & South-Central America & NPP & $\mathrm{O} 2$ & 285 & 1 & (Rivera-Monroy et al., 1998) \\
\hline Etang de Berre & FRANCE & Europe & $\mathrm{U}$ & $14 \mathrm{C}$ & 290 & 2 & (Kim, 1983) \\
\hline Fehmarn Belt & DENMARK & Baltic & $\mathrm{U}$ & $14 \mathrm{C}$ & 170 & 6 & (AErtebjerg et al., 1981) \\
\hline Flax Pond & USA & North America & NPP & $14 \mathrm{C}$ & 12 & 1 & (Moll, 1977) \\
\hline Fourleague Bay & USA & North America & GPP & $\mathrm{O} 2$ & 418 & 2 & (Randall and Day Jr, 1987) \\
\hline Fourleague Bay & USA & North America & NPP & $\mathrm{O} 2$ & 219 & 2 & (Randall and Day Jr, 1987) \\
\hline Funka Bay & JAPAN & Asia & NPP & $14 \mathrm{C}$ & 100 & 1 & (Maita and Yanada, 1978) \\
\hline German Wadden Sea & GERMANY & Europe & GPP & $14 \mathrm{C}$ & 150 & 2 & (Tillman et al., 2000) \\
\hline German Wadden Sea & GERMANY & Europe & NPP & $14 \mathrm{C}$ & 119 & 2 & (Tillman et al., 2000) \\
\hline Golfe du Lion & FRANCE & Europe & GPP & $14 \mathrm{C}$ & 145 & 1 & (Conan et al., 1998) \\
\hline Golfo de Nicoya & COSTA RICA & South-Central America & GPP & $\mathrm{O} 2$ & 747 & 1 & (Gocke et al., 2001a) \\
\hline Golfo de Nicoya & COSTA RICA & South-Central America & NPP & $\mathrm{O} 2$ & 444 & 1 & (Gocke et al., 2001a) \\
\hline Great Belt & DENMARK & Baltic & GPP & $14 \mathrm{C}$ & 59 & 4 & (Steeman Nielsen, 1958) \\
\hline Great Belt & DENMARK & Baltic & $\mathrm{U}$ & $14 \mathrm{C}$ & 170 & 9 & (Ærtebjerg et al., 1981) \\
\hline Great South Bay & USA & North America & NPP & $14 \mathrm{C}$ & 450 & 1 & (Lively et al., 1983) \\
\hline Gulf of Bothnia & FINLAND/SWEDEN & Baltic & $\mathrm{U}$ & $14 C$ & 78 & 1 & (Fonselius, 1972) \\
\hline Gulf of Finland & FINLAND & Baltic & $U$ & $14 \mathrm{C}$ & 45 & 42 & (Lehmusluoto and Pesonen, 1973) \\
\hline Gulf of Trieste & ITALY & Europe & $U$ & $14 \mathrm{C}$ & 150 & 3 & (Umani et al., 2007) \\
\hline Gullmar Fjord & SWEDEN & Europe & U & $14 \mathrm{C}$ & 235 & 24 & $\begin{array}{l}\text { (Lindahl et al., 1998), and O. Lindahl, personal } \\
\text { communication, } 25 \text { June } 2009\end{array}$ \\
\hline High Venice Lagoon & ITALY & Europe & U & $14 \mathrm{C}$ & 147 & 1 & (Vatova, 1961) \\
\hline Howe Sound & CANADA & North America & $U$ & $14 \mathrm{C}$ & 106 & 20 & (Stockner, 1977) \\
\hline Huizache-Caimanero Lagoon & MEXICO & South-Central America & $U$ & $\mathrm{O} 2$ & 894 & 1 & (Edwards, 1978) \\
\hline Ilkwang Bay & KOREA & Asia & $U$ & $14 \mathrm{C}$ & 200 & 1 & (Kang and Kang, 2005) \\
\hline
\end{tabular}




\begin{tabular}{|c|c|c|c|c|c|c|c|}
\hline Indian Arm Fjord & CANADA & North America & GPP & $\mathrm{O} 2$ & 609 & 1 & (Gilmartin, 1964) \\
\hline Indian Arm Fjord & CANADA & North America & NPP & $\begin{array}{c}\text { O2 \& } \\
14 C\end{array}$ & 455 & 1 & (Gilmartin, 1964) \\
\hline Isefjord & DENMARK & Baltic & GPP & $14 C$ & 175 & 1 & (Steeman Nielsen, 1958) \\
\hline Kaneohe Bay & USA & North America & NPP & $14 \mathrm{C}$ & 230 & 8 & (Smith et al., 1981) cited in (Heip et al., 1995) \\
\hline Karrebæksminde Bugt & DENMARK & Baltic & GPP & $14 \mathrm{C}$ & 60 & 1 & (Steeman Nielsen, 1957) \\
\hline Kattegat & DENMARK/ SWEDEN & Baltic & GPP & $14 C$ & 142 & 118 & $\begin{array}{l}\text { (Steeman Nielsen, 1958; Carstensen et al., 2003), } \\
\text { http://mads.dmu.dk }\end{array}$ \\
\hline Kattegat & DENMARK/ SWEDEN & Baltic & NPP & $14 C$ & 121 & 117 & $\begin{array}{l}\text { (Steeman Nielsen, 1958; Carstensen et al., 2003), } \\
\text { http://mads.dmu.dk }\end{array}$ \\
\hline Kattegat & DENMARK/ SWEDEN & Baltic & $\mathrm{U}$ & $14 \mathrm{C}$ & 105 & 14 & (ÆErtebjerg et al., 1981) \\
\hline Kungsbacka Fjord & SWEDEN & Europe & GPP & $14 \mathrm{C}$ & 100 & 1 & (Olsson and Ölundh, 1974) \\
\hline Kviturdvikpollen & NORWAY & Europe & $\mathrm{U}$ & $14 \mathrm{C}$ & 230 & 1 & (Wassman and Aadnesen, 1984) \\
\hline Laholm Bay & SWEDEN & Europe & $\mathrm{U}$ & $14 \mathrm{C}$ & 167 & 10 & (Rydberg et al., 2006) \\
\hline Lake Grevelingen & NETHERLANDS & Europe & $\mathrm{U}$ & $14 \mathrm{C}$ & 196 & 6 & (Vegter and de Visscher, 1984) \\
\hline Limfjord & DENMARK & Baltic & GPP & $14 \mathrm{C}$ & 105 & 1 & (Steeman Nielsen, 1958) \\
\hline Loch Etive & SCOTLAND & Europe & U & $14 \mathrm{C}$ & 70 & 2 & (Wood et al., 1973) \\
\hline Loch Thurnaig & SCOTLAND & Europe & $\mathrm{U}$ & $14 \mathrm{C}$ & 111 & 1 & (Davies, 1975) cited in (Boynton, 1982) \\
\hline Logan River & AUSTRALIA & Australia-New Zealand & $\mathrm{U}$ & $14 \mathrm{C}$ & 212 & 1 & (O'Donohue and Dennison, 1997) \\
\hline Long Island Sound & USA & North America & GPP & $\mathrm{O} 2$ & 470 & 1 & (Riley, 1956) \\
\hline Long Island Sound & USA & North America & NPP & $\mathrm{O} 2$ & 400 & 3 & (Riley, 1956; Goebel et al., 2006) \\
\hline Lower St. Lawrence Estuary & USA / CANADA & North America & $\mathrm{U}$ & $14 \mathrm{C}$ & 100 & 29 & (Therriault and Levasseur, 1985) \\
\hline Lynher Estuary & UNITED KINGDOM & Europe & $\mathrm{U}$ & $14 \mathrm{C}$ & 82 & 1 & (Joint, 1978) \\
\hline Manahawkin Estuary & USA & North America & GPP & $\mathrm{O} 2$ & 198 & 5 & (Durand et al., 1979) \\
\hline Manahawkin Estuary & USA & North America & NPP & $\mathrm{O} 2$ & 31 & 5 & (Durand et al., 1979) \\
\hline $\begin{array}{l}\text { Mandovi-Zuari Estuarine } \\
\text { Complex }\end{array}$ & INDIA & Asia & NPP & $14 \mathrm{C}$ & 300 & 3 & (Krishna Kumari et al., 2002) \\
\hline Massachusetts Bay & USA & North America & $U$ & $14 \mathrm{C}$ & 481 & 22 & (Oviatt et al., 2007) \\
\hline Mecklenburg Bight & DENMARK & Baltic & $\mathrm{U}$ & $14 \mathrm{C}$ & 134 & 7 & (ÆErtebjerg et al., 1981) \\
\hline Mikawa Bay & JAPAN & Asia & $U$ & $\mathrm{O} 2$ & 770 & 1 & (Marba et al., 2006) cited in (Ara et al., 2011) \\
\hline Mississippi Sound & USA & North America & $\mathrm{U}$ & $14 \mathrm{C}$ & 468 & 1 & (Moncreiff et al., 1992) \\
\hline Morlaix Bay & FRANCE & Europe & $U$ & $14 \mathrm{C}$ & 314 & 1 & (Wafar et al., 1983) \\
\hline Nanaimo Estuary & CANADA & North America & $U$ & $14 \mathrm{C}$ & 97 & 4 & (Brown et al., 1976) \\
\hline
\end{tabular}




\begin{tabular}{|c|c|c|c|c|c|c|c|}
\hline Narragansett Bay & USA & North America & GPP & $14 \mathrm{C}$ & 237 & 17 & (Keller, 1988; Oviatt, 2002) \\
\hline Narragansett Bay & USA & North America & NPP & $\begin{array}{c}\text { O2 \& } \\
14 C\end{array}$ & 236 & 8 & (Keller, 1988; Oviatt et al., 1981) \\
\hline Neuse River Estuary & USA & North America & U & $14 C$ & 358 & 12 & $\begin{array}{l}\text { (Boyer et al., 1993; Mallin et al., 1991; Mallin et al., 1993; } \\
\text { Fisher et al., 1982) }\end{array}$ \\
\hline New York Bight & USA & North America & $\mathrm{U}$ & $14 \mathrm{C}$ & 370 & 1 & (Malone, 1976) \\
\hline Nordësvannet & NORWAY & Europe & $\mathrm{U}$ & $14 \mathrm{C}$ & 190 & 1 & (Wassman et al., 1986) cited in (Heip et al., 1995) \\
\hline North San Francisco Bay & USA & North America & GPP & $14 \mathrm{C}$ & 130 & 4 & (Cole and Cloern, 1984) \\
\hline North San Francisco Bay & USA & North America & NPP & $14 \mathrm{C}$ & 104 & 4 & (Cole and Cloern, 1984) \\
\hline Oosterschelde & NETHERLANDS & Europe & U & $14 C$ & 280 & 26 & $\begin{array}{l}\text { (Vegter and De Visscher, 1987; Wetsteyn and Kromkamp, } \\
\text { 1994) }\end{array}$ \\
\hline Osaka Bay & JAPAN & Asia & $\mathrm{U}$ & $13 \mathrm{C}$ & 825 & 1 & (Yamaguchi and Imai, 1996) cited in (Ara et al., 2011) \\
\hline Pamlico River & USA & North America & $\mathrm{U}$ & $14 \mathrm{C}$ & 500 & 6 & (Kuenzler et al., 1979) \\
\hline Patuxent River Estuary & USA & North America & GPP & $14 \mathrm{C}$ & 126 & 26 & (Flemer, 1970) \\
\hline Peconic Bay Estuary & USA & North America & U & $14 \mathrm{C}$ & 177 & 2 & (Bruno et al., 1980) \\
\hline Petalion Gulf & GREECE & Europe & GPP & $14 \mathrm{C}$ & 33 & 1 & (Becacos-Kontos, 1977) \\
\hline Phanga Bay & THAILAND & Asia & GPP & $14 \mathrm{C}$ & 468 & 1 & (Wium-Anderson, 1979) \\
\hline Pichavaram & INDIA & Asia & GPP & $\mathrm{O} 2$ & 113 & 1 & (Purvaja and Ramesh, 2000) \\
\hline Port Hacking Estuary & AUSTRALIA & Australia-New Zealand & $\mathrm{U}$ & $14 \mathrm{C}$ & 237 & 1 & (Scott, 1979) \\
\hline Puget Sound & USA & North America & U & $14 \mathrm{C}$ & 370 & 4 & (Winter et al., 1975) \\
\hline Raunefjorden & NORWAY & Europe & $\mathrm{U}$ & $14 \mathrm{C}$ & 230 & 1 & (Wassman and Aadnesen, 1984) \\
\hline Rhode River Estuary & USA & North America & U & $14 \mathrm{C}$ & 402 & 20 & $\begin{array}{l}\text { (Gallegos, 2014); and C.L. Gallegos, personal } \\
\text { communication, } 28 \text { May } 2013\end{array}$ \\
\hline Riá de Vigo & SPAIN & Europe & GPP & $\mathrm{O} 2$ & 520 & 1 & (Cermeño et al., 2006) \\
\hline Riá de Vigo & SPAIN & Europe & U & $14 \mathrm{C}$ & 260 & 1 & (Fraga, 1976) \\
\hline Roskeeda Bay & IRELAND & Europe & GPP & $\mathrm{O} 2$ & 74 & 1 & (Raine and Patching, 1980) \\
\hline Roskeeda Bay & IRELAND & Europe & NPP & $\mathrm{O} 2$ & 4 & 1 & (Raine and Patching, 1980) \\
\hline Saanich Inlet & CANADA & North America & GPP & $13 \mathrm{C}$ & 460 & 2 & (Grundle et al., 2009) \\
\hline Sagami Bay & JAPAN & Asia & NPP & $13 \mathrm{C}$ & 366 & 3 & (Ara and Hiromi, 2009, 2007; Ara et al., 2011) \\
\hline Sams $\varnothing$ Belt & DENMARK & Baltic & $\mathrm{U}$ & $14 \mathrm{C}$ & 218 & 2 & (AErtebjerg et al., 1981) \\
\hline Scheldt Estuary & BELGIUM & Europe & GPP & $\mathrm{O} 2$ & 153 & 5 & (Gazeau et al., 2005) \\
\hline Scheldt Estuary & BELGIUM & Europe & NPP & $\mathrm{O} 2$ & -105 & 5 & (Gazeau et al., 2005) \\
\hline Seto Inland Sea of Japan & JAPAN & Asia & $\mathrm{U}$ & $14 \mathrm{C}$ & 120 & 1 & (Endo, 1970) \\
\hline
\end{tabular}




\begin{tabular}{|c|c|c|c|c|c|c|c|}
\hline Shijiki Bay & JAPAN & Asia & $\mathrm{U}$ & 02 & 292 & 1 & (Kimoto et al., 1987) cited in (Ara et al., 2011) \\
\hline South San Francisco Bay & USA & North America & GPP & $14 \mathrm{C}$ & 185 & 2 & (Cole and Cloern, 1984) \\
\hline South San Francisco Bay & USA & North America & NPP & $14 \mathrm{C}$ & 150 & 2 & (Cole and Cloern 1984) \\
\hline St. Lawrence System & CANADA & North America & $\mathrm{U}$ & $14 \mathrm{C}$ & 212 & 5 & (Steven, 1974; Mclver, 1972) \\
\hline St. Margaret's Bay & CANADA & North America & $U$ & $14 \mathrm{C}$ & 253 & 2 & (Platt, 1971) \\
\hline Strait of Georgia & CANADA & North America & $\mathrm{U}$ & $14 \mathrm{C}$ & 346 & 16 & (Stockner and Cliff, 1979) \\
\hline Swan River Estuary & AUSTRALIA & Australia-New Zealand & GPP & $14 \mathrm{C}$ & 803 & 9 & (Thompson, 1998) \\
\hline Swartvlei & SOUTH AFRICA & Africa & U & $14 \mathrm{C}$ & 100 & 1 & (Robarts, 1976) cited in (Boynton, 1982) \\
\hline Sylt-Røm $\varnothing$ Bight & GERMANY & Europe & GPP & $\mathrm{O} 2$ & 161 & 1 & (Asmus et al., 1998) \\
\hline Tagus Estuary & PORTUGAL & Europe & GPP & $14 \mathrm{C}$ & 85 & 2 & (Gameiro et al., 2011) \\
\hline Tamagawa Estuary & JAPAN & Asia & NPP & $14 \mathrm{C}$ & 1890 & 1 & (Yamaguchi et al., 1991) \\
\hline Tampa Bay & USA & North America & GPP & $14 \mathrm{C}$ & 432 & 68 & $\begin{array}{l}\text { (Johansson, 2010) and J.O.R. Johansson, personal } \\
\text { communication, } 21 \text { August } 2013\end{array}$ \\
\hline Tasman Bay & NEW ZEALAND & Australia-New Zealand & U & $14 \mathrm{C}$ & 146 & 2 & (Mackenzie and Gillespie, 1986) \\
\hline Terminos Lagoon & MEXICO & South-Central America & NPP & $\mathrm{O} 2$ & 222 & 3 & (Day et al., 1982; Day et al., 1988) \\
\hline Tokyo Bay & JAPAN & Asia & GPP & $13 \mathrm{C}$ & 482 & 6 & (Bouman et al., 2010) \\
\hline Tomales Bay & USA & North America & $\mathrm{U}$ & $14 \mathrm{C}$ & 414 & 10 & (Cole, 1989) \\
\hline Tosa Bay & JAPAN & Asia & $\mathrm{U}$ & $13 \mathrm{C}$ & 274 & 2 & $\begin{array}{l}\text { (Ichikawa and Hirota, 2004) cited in (Ara et al., 2011), } \\
\text { (Yokouchi et al., 2007) }\end{array}$ \\
\hline Tvärminne Archipelago & FINLAND & Baltic & $\mathrm{U}$ & $14 \mathrm{C}$ & 61 & 10 & (Niemi, 1975; Lignell, 1990) \\
\hline Vågsböpollen & NORWAY & Europe & $\mathrm{U}$ & $14 \mathrm{C}$ & 180 & 1 & (Wassman and Aadnesen, 1984) \\
\hline Ven $\varnothing$ Bugt & DENMARK & Baltic & GPP & $14 \mathrm{C}$ & 105 & 1 & (Steeman Nielsen, 1957) \\
\hline Wassaw Sound & USA & North America & NPP & $14 \mathrm{C}$ & 90 & 6 & (Turner et al., 1979) \\
\hline Westerschelde & $\begin{array}{l}\text { NETHERLANDS/ } \\
\text { BELGIUM }\end{array}$ & Europe & GPP & $14 \mathrm{C}$ & 190 & 14 & (Kromkamp et al., 1995) \\
\hline Westerschelde & $\begin{array}{l}\text { NETHERLANDS/ } \\
\text { BELGIUM }\end{array}$ & Europe & U & $14 \mathrm{C}$ & 180 & 11 & (Van Spaendonk et al., 1993) \\
\hline Young Sound & GREENLAND & Europe & $U$ & $14 \mathrm{C}$ & 10 & 1 & (Rysgaard et al., 1999) \\
\hline
\end{tabular}




\section{References}

Ærtebjerg, G., T.S. Jacobsen, E. Gargas and E. Buch: The Belt Project. Evaluation of the physical , chemical and biological measurements, The National Agency of Environmental Protection, Denmark, 122 pages, ISBN 8750335324 9788750335320, 1981.

Anderson, G. C.: The Seasonal and Geographic Distribution of Primary Productivity Off the Washington and Oregon Coasts, Limnology and Oceanography, 9, 284302, 1964.

Apollonio, S.: Primary production in Dumbell Bay in the Arctic Ocean, Marine Biology, 61, 41-51, 1980.

Ara, K., and Hiromi, J.: Temporal variability in primary and copepod production in Sagami Bay, Japan, Journal of Plankton Research, 29, Supplement 1, i85-i96, 2007.

Ara, K., and Hiromi, J.: Seasonal Variability in Plankton Food Web Structure and Trophodynamics in the Neritic Area of Sagami Bay, Japan, Journal of Oceanography, 65, 757-779, 2009.

Ara, K., Yamaki, K., Wada, K., Fukuyama, S., Okutsu, T., Nagasaka, S., Shiomoto, A., and Hiromi, J.: Temporal variability in physicochemical properties, phytoplankton standing crop and primary production for 7 years (2002-2008) in the neritic area of Sagami Bay, Japan, Journal of Oceanography, 67, 87-111, 10.1007/s10872-011-0010-y, 2011.

Asmus, R., Jensen, M. H., Murphy, D., and Doerffer, R.: Primary Production of Microphytobenthos, Phytoplankton and the Annual Yield of Macrophytic Biomass in the Sylt-Rømø Wadden Sea, in: The Wadden Sea Ecosystem: Exchange, Transport, and Transformation Processes, edited by: Gätje, C. and Reise, K., Springer, Berlin, 367-392, 1998.

Azevedo, I., Duarte, P., and Bordalo, A.: Pelagic metabolism of the Douro estuary (Portugal) - Factors controlling primary production, Estuarine, Coastal and Shelf Science, 69, 133-146, 10.1016/j.ecss.2006.04.002, 2006.

Becacos-Kontos, T.: Primary production and environmental factors in an oligotrophic biome in the Aegean Sea, Marine Biology, 42, 93-98, 1977.

Bouman, H. A., Nakane, T., Oka, K., Nakata, K., Kurita, K., Sathyendranath, S., and Platt, T.: Environmental controls on phytoplankton production in coastal ecosystems: A case study from Tokyo Bay, Estuarine, Coastal and Shelf Science, 87, 63-72, 10.1016/j.ecss.2009.12.014, 2010.

Boyer, J. N., Christian, R. R., and Stanley, D. W.: Patterns of phytoplankton primary productivity in the Neuse River estuary, North Carolina, USA, Marine Ecology Progress Series, 97, 287-297, 1993. 
Boynton, W. R.: Phytoplankton Production in Chincoteague Bay, Maryland-Virginia, PhD Thesis, University of North Carolina, Chapel Hill, 284 pp., 1973.

Boynton, W. R., W. M. Kemp, and C. W. Keefe.: A comparative analysis of nutrients and other factors influencing estuarine phytoplankton production, in: Estuarine Comparisons, edited by: Kennedy, V. S., Academic Press, New York, 69-90, 1982.

Brkich, W. S.: Phytoplankton productivity in the Barataria Bay area of Louisiana, Ph.D. dissertation, Louisiana State University, Baton Rouge, Louisiana, 1972.

Brown, T. J., Sibert, J., and Stephens, K.: Data pertaining to the lower trophic levels of Nanaimo River Estuary and adjacent waters from March 1974 to March 1975, Department of Fisheries and Oceans, Fisheries and Marine Service Data Record No. 20, Nanaimo, B.C., 1976.

Bruno, S. F., Staker, R. D., and Sharma, G. M.: Dynamics of Phytoplankton Productivity in the Peconic Bay Estuary, Long Island, Estuarine and Coastal Marine Science, 10, 247-263., 1980.

Cadée, G. C., and Hegeman, J.: Phytoplankton primary production, chlorophyll, and composition in an inlet of the western Wadden Sea (Marsdiep), Netherlands Journal of Sea Research, 13, 224-241, 1979.

Cadée, G. C., and Hegeman, J.: Persisting High Levels of Primary Production at Declining Phosphate Concentrations in the Dutch Coastal Area (Marsdiep), Netherlands Journal of Sea Research, 31, 147-152, 1993.

Carstensen, J., Conley, D., and Muller-Karulis, B.: Spatial and temporal resolution of carbon fluxes in a shallow coastal ecosystem, the Kattegat, Marine EcologyProgress Series, 252, 35-50, 2003.

Cermeño, P., Marañón, E., Pérez, V., Serret, P., Fernández, E., and Castro, C. G.: Phytoplankton size structure and primary production in a highly dynamic coastal ecosystem (Ría de Vigo, NW-Spain): Seasonal and short-time scale variability, Estuarine, Coastal and Shelf Science, 67, 251-266, DOI: 10.1016/j.ecss.2005.11.027, 2006.

Cole, B. E., and Cloern, J. E.: Significance of biomass and light availability to phytoplankton productivity in San Francisco Bay, Marine Ecology Progress Series, 17, $15-24,1984$.

Cole, B. E.: Temporal and Spatial Patterns of Phytoplankton Production in Tomales Bay, California, U.S.A., Estuarine, Coastal and Shelf Science, 28, 103-115, 1989.

Colijn, F., and Ludden, E.: The primary production of phytoplankton in the Ems-Dollard estuary, in: Primary Production in the Ems-Dollard Estuary, edited by: F. Colijn, PhD Thesis, Rijksuniversiteit, Groningen, 38-99, 1983. 
Conan, P., Pujo-Pay, M., Raimbault, P., and Leveau, M.: Hydrological and biological variability in the Gulf of Lions. I. Nitrogen fluxes and potential productivity, Oceanologica Acta, 21, 751-765, 1998.

Davies, J. M.: Energy flow through the benthos in a Scottish Sea Loch, Marine Biology, 31, 353-362, 1975.

Day, J. W., Smith, W. B., Stowe, W., and Wagner, P.: Community structure and carbon budget in a salt marsh and shallow bay estuarine system in Louisiana, Center for Wetland Resources, Louisiana State University Publication Number LSU-SG-72-04, 1973.

Day, J. W., Day, R. H., Barreiro, M. T., Ley-Lou, F., and Madden, C. J.: Primary production in the Laguna de Terminos, a tropical estuary in the Southern Gulf of Mexico, Oceanologica Acta, 269-276, 1982.

Day, J. W., Ley-Lou, F., Wetzel, R. L., and Machado, A.: Aquatic primary productivity in Terminos Lagoon, in: Ecology of Coastal Ecosystems in the Southern Gulf of Mexico: The Terminos Lagoon Region, edited by: A. Yanez-Arancibia and J.W. Day, Instituto de Ciencias del Mar y Limnologia, Universidad Nacional Autonomo de Mexico, Editorial Universitaria, Mexico D.F., 221-235, 1988.

Del Amo, Y., Le Pape, O., Treguer, P., Queguiner, B., Menesguen, A., and Aminot, A.: Impacts of high-nitrate freshwater inputs on macrotidal ecosystems. I. Seasonal evolution of nutrient limitation for the diatom-dominated phytoplankton of the Bay of Brest (France). Marine Ecology Progress Series, $161,213-224,1997$.

Durand, J. B., Sugihara, T., and Yearsley, C. E.: Estuarine evaluation study: primary aquatic production and nitrogen. Four year report, 1973-1977, Comparison of natural and altered estuarine systems: The field data - Volumes I and II, edited by: Sugihara, T., Psuty, N. P., and Durand, J. B., Center for Coastal and Environmental Studies, Rutgers University, New Brunswick, N.J., 1979.

Edwards, R. R. C.: Ecology of a coastal lagoon complex in Mexico, Estuarine and Coastal Marine Science, 6, 75-92., 1978.

Eilertsen, H. C., and Taasen, J. P.: Investigations on the plankton community of Balsforden, northern Norway. The phytoplankton 1976-1978. Environmental factors, dynamics of growth, and primary production., Sarsia, 69, 1-15, 1984.

Endo, T.: On primary production in the Seto Inland Sea, Journal of the Faculty of Fisheries and Animal Husbandry, Hiroshima University, 9, 177-221, 1970.

Fisher, T. R., Carlson, P. R., and Barber, R. T.: Carbon and nitrogen primary productivity in three North Carolina estuaries, Estuarine, Coastal and Shelf Science, 15, $621-644,1982$

Flemer, D. A.: Primary Production in the Chesapeake Bay, Chesapeake Science, 11, 117-129, 1970. 
Flores-Verdugo, F. J., Day, J. W., Mee, L., and Briseño-Dueñas, R.: Phytoplankton production and seasonal biomass variation of seagrass, Ruppia maritima L., in a tropical Mexican lagoon with an ephemeral inlet, Estuaries, 11, 51-56, 1988.

Fonselius, S. H.: On biogenic elements and organic matter in the Baltic, Ambio Special Report, 1, 29-36, 1972.

Fraga, F.: Fotosintesis en la ria de Vigo, Inv. Pesq., 40, 151-167, 1976.

Gallegos, C. L.: Long-term variations in primary production in a eutrophic sub-estuary: 1. Seasonal and spatial variability, Marine Ecology Progress Series (in press, doi:10.3354/meps10712), 2014.

Gameiro, C., Zwolinski, J., and Brotas, V.: Light control on phytoplankton production in a shallow and turbid estuarine system, Hydrobiologia, 669, 249-263, 10.1007/s10750-011-0695-3, 2011.

Gazeau, F., Gattuso, J.-P., Middelburg, J., Brion, N., Schiettecatte, L.-S., Frankignoulle, M., and Borges, A.: Planktonic and whole system metabolism in a nutrient-rich estuary (the Scheldt estuary), Estuaries and Coasts, 28, 868-883, 10.1007/bf02696016, 2005.

Gilmartin, M.: The primary production of a British Columbia fjord, Journal of the Fisheries Research Board of Canada, 21, 505-538., 1964.

Glé, C., Del Amo, Y., Sautour, B., Laborde, P., and Chardy, P.: Variability of nutrients and phytoplankton primary production in a shallow macrotidal coastal ecosystem (Arcachon Bay, France), Estuarine, Coastal and Shelf Science, 76, 642-656, DOI: 10.1016/j.ecss.2007.07.043, 2008.

Gocke, K., Cortés, J., and Murillo, M. M.: The annual cycle of primary productivity in a tropical estuary: The inner regions of the Golfo de Nicoya, Costa Rica, Revista de Biologia Tropical, 49, 289-306, 2001a.

Gocke, K., Cortés, J., and Murillo, M. M.: Planktonic primary production in a tidally influenced mangrove forest on the Pacific coast of Costa Rica, Revista de Biologia Tropical, 49, 279-288, 2001b.

Goebel, N. L., Kremer, J. N., and Edwards, C. A.: Primary production in Long Island Sound, Estuaries and Coasts, 29, 232-245, 2006.

Grundle, D. S., Timothy, D. A., and Varela, D. E.: Variations of phytoplankton productivity and biomass over an annual cycle in Saanich Inlet, a British Columbia fjord, Continental Shelf Research, 29, 2257-2269, 10.1016/j.csr.2009.08.013, 2009.

Harding, L. W. Jr., Mallonee, M. E., and Perry, E. S.: Toward a Predictive Understanding of Primary Productivity in a Temperate, Partially Stratified Estuary, Estuarine, Coastal and Shelf Science, 55, 437-463, DOI: 10.1006/ecss.2001.0917, 2002. 
Heip, C. H. R., Goosen, N. K., Herman, P. M. J., Kromkamp, J., Middelburg, J., and Soetaert, K.: Production and consumption of biological particles in temperate estuaries., Oceanogr Mar Biol Ann Rev, 33, 1-149, 1995.

Hernandez, C. A., and Gocke, K.: Productividad primaria en la Ciénaga Grande de Santa Marta, Colombia., Anales del Instituto de Investigaciones Marinas de Punta de Betin., 19-20, 101-119, 1990

Ichikawa, T., and Hirota, Y.: Seasonal changes of primary productivity in Tosa Bay, Japan, Oceanogr Japan, 13, 259-269, 2004.

Johansson, J. O. R.: Long-term and seasonal trends in phytoplankton production and biomass in Tampa Bay, Florida, in: Proceedings, Tampa Bay Area Scientific Information Symposium, BASIS 5: 20-23 October 2009, edited by: Cooper, S. T., available at: http://www.tbeptech.org/BASIS/BASIS5/BASIS5.pdf, (last access: 2 November 2013), 73-94, 2010.

Joint, I. R.: Microbial production of an estuarine mudflat, Estuarine and Coastal Marine Science, 7, 185-195, Doi: 10.1016/0302-3524(78)90074-9, 1978.

Joint, I. R., and Pomroy, A. J.: Primary production in a turbid estuary, Estuarine, Coastal and Shelf Science, 13, 303-316, 1981.

Jørgensen, B. B.: Case study - Aarhus Bay, in: Eutrophication in Coastal Marine Ecosystems, edited by Jørgensen, B. B. and Richardson, K., American Geophysical Union, Coastal and Estuarine Studies, 52, 137-154, 1996. DOI: 10.1029/CE052

Kang, H.-K., and Kang, Y. J.: Production of Acartia steueri (Copepoda: Calanoida) in Ilkwang Bay, Southeastern Coast of Korea, Journal of Oceanography, 61, 327334, 10.1007/s10872-005-0043-1, 2005.

Keller, A. A.: Estimating Phytoplankton Productivity from Light Availability and Biomass in the MERL Mesocosms and Narragansett Bay, Marine Ecology-Progress Series, 45, 159-168, 1988

Kim, K. T.: Production primaire pélagique de l'Etang de Berre en 1977 et 1978. Comparaison avec le milieu marin (Méditerranée nord-occidentale), Marine Biology, 73, 325-341, 1983

Kimoto K., Nakashima J., Morioka Y.: Standing stock of chlorophyll a and primary productivity in a small inlet of Kyushu, Bull Seikai Reg Fish Lab 64, 35-46, 1987.

Kocum, E., Underwood, G. J. C., and Nedwell, D. B.: Simultaneous measurement of phytoplanktonic primary production, nutrient and light availability along a turbid, eutrophic UK east coast estuary (the Colne Estuary), Marine Ecology Progress Series, 231, 1-12, 2002.

Krishna Kumari, L., Bhattathiri, P. M. A., Matondkar, S. G. P., and John, J.: Primary productivity in Mandovi-Zuari estuaries in Goa, J. mar. biol. Ass. India, 44, 1-13, 2002. 
Kromkamp, J., Peene, J., Rijswijk, P., Sandee, A., and Goosen, N.: Nutrients, light and primary production by phytoplankton and microphytobenthos in the eutrophic, turbid Westerschelde estuary (The Netherlands), Hydrobiologia, 311, 9-19, 10.1007/bf00008567, 1995.

Kuenzler, E. J., Stanley, D. W., and Koenings, J. P.: Nutrient kinetics of phytoplankton in the Pamlico River, North Carolina, Water Resources Research Institute of the University of North Carolina, Report 79-139, available at: http://repository.lib.ncsu.edu/dr/bitstream/1840.4/1755/1/NC-WRRI-139.pdf (last access 8 March 2014),1979.

Lara-Lara, J. R., Frey, B. E., and Small, L. F.: Primary production in the Columbia River Estuary II. Grazing losses, transport, and a phytoplankton carbon budget, Pacific Science, 44, 1990.

Lehmusluoto, P. O., and Pesonen, L.: Eutrophication in the Helsinki and Espoo Sea areas measured as phytoplankton primary production, Oikos Supplementum, 15, 202-208., 1973.

Lignell, R.: Excretion of organic carbon by phytoplankton: its relation to algal biomass, primary productivity and bacterial secondary productivity in the Baltic Sea, Marine Ecology Progress Series, 68, 85-99, 1990.

Lindahl, O., Belgrano, A., Davidsson, L., and Hernroth, B.: Primary production, climatic oscillations, and physico-chemical processes: The Gullmar Fjord time-series data set (1985-1996), ICES Journal of Marine Science, 55, 723-729, 1998.

Lively, J. S., Kaufman, Z., and Carpenter, E. J.: Phytoplankton ecology of a barrier island estuary: Great South Bay, New York, Estuarine, Coastal and Shelf Science, $16,51-68,1983$

Loebl, M., Dolch, T., and van Beusekom, J. E. E.: Annual dynamics of pelagic primary production and respiration in a shallow coastal basin, Journal of Sea Research, 58, 269-282, DOI: 10.1016/j.seares.2007.06.003, 2007.

Mackenzie, A. L., and Gillespie, P. A.: Plankton ecology and productivity, nutrient chemistry, and hydrography of Tasman Bay, New Zealand, 1982-1984, New Zealand Journal of Marine and Freshwater Research, 20, 365-396, 1986

Maita, Y., and Yanada, M.: Particulate protein in coastal waters, with special reference to seasonal variation, Marine Biology, 44, 329-336, 1978.

Mallin, M. A., Paerl, H. W., and Rudek, J.: Seasonal phytoplankton composition, productivity and biomass in the Neuse River estuary, North Carolina, Estuarine, Coastal and Shelf Science, 32, 609-623, 1991. 
Mallin, M. A., Paerl, H. W., Rudek, J., and Bates, P. W.: Regulation of estuarine primary production by watershed rainfall and river flow, Marine Ecology Progress Series, 93, 199-203, 1993.

Malone, T. C.: Phytoplankton productivity in the apex of the New York Bight: Environmental regulation of productivity/chlorophyll $a$, in: Proceedings of the Symposium, Middle Atlantic Continental Shelf and the New York Bight, edited by: M.G. Gross, American Society of Limnology and Oceanography, Special Symposia $2,260-272,1976$

Marba, N., Hemminga, M. A., and Duarte, C. M.: Resource translocation within seagrass clones: allometric scaling to plant size and productivity, Oecologia, 150, 362-372, 10.1007/s00442-006-0524-y, 2006.

McIver, A. H.: Primary and secondary production of Malpeque Bay, Prince Edward Island, compared with one of its tributaries and the nearby Gulf of St. Lawrence., M.Sc. Thesis, Department of Biology, McGill University, Montreal, Quebec, 83p. pp., 1972.

Moll, R. A.: Phytoplankton in a temperate-zone salt marsh: Net production and exchanges with coastal waters., Marine Biology, 42, 109-118, 1977.

Moncreiff, C., Sullivan, M., and Daehnick, A.: Primary production dynamics in seagrass beds of Mississippi Sound - The contributions of seagrass, epiphytic algae, sand microflora, and phytoplankton., Marine Ecology Progress Series, 87, 161-171, 1992.

Mortazavi, B., Iverson, R. L., Landing, W. M., Lewis, F. G., and Huang, W.: Control of phytoplankton production and biomass in a river-dominated estuary: Apalachicola Bay, Florida, USA, Marine Ecology Progress Series, 198, 19-31, 2000.

Niemi, A.: Ecology of phytoplankton in the Tvarminne area, SW coast of Finland., Acta Botanica Fennica, 1975.

Nixon, S. W., and Oviatt, C. A.: Ecology of a New England salt marsh, Ecological Monographs, 43, 463-498, 1973.

Nixon, S. W., and Lee, V.: The flux of carbon, nitrogen and phosphorous between coastal lagoons and offshore waters, Seminar on Coastal Lagoon Research, Present and Future. 29 Aug 1978, Beaufort, N.C., 1981.

Nixon, S. W.: Nutrient dynamics, primary production and fisheries yields of lagoons, Oceanologica Acta, 357-371, 1982.

O'Donohue, M. J. H., and Dennison, W. C.: Phytoplankton productivity response to nutrient concentrations, light availability and temperature along an Australian estuarine gradient, Estuaries, 20, 521-533, 1997.

Olsson, I., and Ölundh, E.: On plankton production in Kungsbacka Fjord, an estuary on the Swedish west coast, Marine Biology, 24, 17-28, 1974. 
Oviatt, C., Buckley, B., and Nixon, S.: Annual Phytoplankton Metabolism in Narragansett Bay Calculated from Survey Field Measurements and Microcosm Observations, Estuaries, 4, 167-175, 1981.

Oviatt, C.: Annual Primary Production in Narragansett Bay with no Bay-Wide Winter-Spring Phytoplankton Bloom, Estuarine, Coastal and Shelf Science, 54, 10131026, 10.1006/ecss.2001.0872, 2002.

Oviatt, C. A., Hyde, K. J. W., Keller, A. A., and Turner, J. T.: Production patterns in Massachusetts Bay with outfall relocation, Estuaries and Coasts, 30, 35-46, 2007.

Pennock, J. R., and Sharp, J. H.: Phytoplankton production in the Delaware Estuary: temporal and spatial variability, Marine Ecology Progress Series, 34, 143-155, 1986.

Philippart, C. J. M., Beukema, J. J., Cadée, G. C., Dekker, R., Goedhart, P. W., Iperen, J. M., Leopold, M. F., and Herman, P. M. J.: Impacts of Nutrient Reduction on Coastal Communities, Ecosystems, 10, 96-119, 10.1007/s10021-006-9006-7, 2007.

Platt, T.: The annual production by phytoplankton in St. Margaret's Bay, Nova Scotia, J. Cons. int. Explor. Mer, 33, 324-333, 1971.

Platt, T.: Analysis of the importance of spatial and temporal heterogeneity in the estimation of annual production by phytoplankton in a small, enriched, marine basin, Journal of Experimental Marine Biology and Ecology, 18, 99-109, 1975.

Purvaja, R., and Ramesh, R.: Natural and anthropogenic effects on phytoplankton primary productivity in mangroves, Chemistry and Ecology, 17, 41-58, 2000.

Qasim, S. Z.: Some problems related to the food chain in a tropical estuary, in: Marine food chains, edited by: Steele, J. H., Oliver and Boyd, Edinburgh, 45-51, 1970.

Ragotzkie, R. A.: Plankton productivity in estuarine waters of Georgia, Publications of the Institute of Marine Science, 6, 146-158, 1959.

Raine, R. C. T., and Patching, J. W.: Aspects of carbon and nitrogen cycling in a shallow marine environment, Journal of Experimental Marine Biology and Ecology, 47, 127-139, Doi: 10.1016/0022-0981(80)90107-0, 1980.

Randall, J. M., and Day J. W. Jr.: Effects of river discharge and vertical circulation on aquatic primary production in a turbid Louisiana (USA) estuary, Netherlands Journal of Sea Research, 21, 231-242, 1987.

Riley, G. A.: Production and utilization of organic matter, Bulletin of the Bingham Oceanographic Collection: Oceanography of Long Island Sound, 1952-1954, XV, $324-344,1956$ 
Rivera-Monroy, V., Madden, C., Day, J., Twilley, R., Vera-Herrera, F., and Alvarez-Guillén, H.: Seasonal coupling of a tropical mangrove forest and an estuarine water column: enhancement of aquatic primary productivity, Hydrobiologia, 379, 41-53, 10.1023/a:1003281311134, 1998.

Robarts, R. D.: Primary Productivity of the Upper Reaches of a South African Estuary (Swartvlei), J. exp. mar. Biol. Ecol., 24, 93-102, 1976.

Roman, M. R., Reeve, M. R., and Froggatt, J. L.: Carbon production and export from Biscayne Bay, Florida. I. Temporal patterns in primary production, seston and zooplankton, Estuarine, Coastal and Shelf Science, 17, 45-59, Doi: 10.1016/0272-7714(83)90044-6, 1983.

Rydberg, L., Ertebjerg, G., and Edler, L.: Fifty years of primary production measurements in the Baltic entrance region, trends and variability in relation to landbased input of nutrients, Journal of Sea Research, 56, 1-16, DOI: 10.1016/j.seares.2006.03.009, 2006.

Rysgaard, S., Nielsen, T. G., and Hansen, B. W.: Seasonal variation in nutrients, pelagic primary production and grazing in a high-Arctic coastal marine ecosystem, Young Sound, Northeast Greenland, Marine Ecology Progress Series, 179, 13-25, 1999.

Sanders, J., and Kuenzler, E.: Phytoplankton population dynamics and productivity in a sewage-enriched tidal Creek in North Carolina, Estuaries, 2, 87-96, $10.2307 / 1351632,1979$.

Sandoval-Rojo, L. C., F. J. F. Verdugo, U. Zaragoza-Araujo, J. W. Day, A. Estrada-Mercado: Phytoplankton productivity in the Barra De Navidad coastal Lagoon on the Pacific coast of Mexico, Revue d'hydrobiologie tropicale., 21, 101-108, 1988.

Scott, B. D.: Seasonal Variation of Phytoplankton Production in an Estuary in Relation to Coastal Water Movements, Australian Journal of Marine and Freshwater Research, 30, 449-461, 1979.

Small, L. F., McIntire, C. D., MacDonald, K. B., Lara-Lara, J. R., Frey, B. E., Amspoker, M. C., and Winfield, T.: Primary production, plant and detrital biomass, and particle transport in the Columbia River Estuary, Prog. Oceanogr., 25, 175-210, Doi: 10.1016/0079-6611(90)90007-o, 1990.

Smith, S. V., Kimmerer, W. J., Laws, E. A., Brock, R. E., and Walsh, T. W.: Kaneohe Bay sewage diversion experiment: perspectives on ecosystem responses to nutritional perturbation, Pacific Science, 35, 279-395, 1981.

Steeman Nielsen, E.: Investigations on the phytoplankton in sheltered Danish marine localities. II. Production of organic matter, Meddelelser fra Kommissionen for Danmarks fiskeri- og havundersogelser. Serie, plankton., 5, 42-52, 1957.

Steeman Nielsen, E.: Experimental methods for measuring organic production in the sea., Rapport et Proces-Verbaux des Reunions Conseil Permanent International pour l'Exploration de la Mer, 144, 38-46, 1958. 
Steven, D. M.: Gulf of St. Lawrence Project: Final Report, McGill University, Montreal, 113p., 1974.

Stockner, J. G., and Cliff, D. D.: Phytoplankton Ecology of Vancouver Harbor, Journal of the Fisheries Research Board of Canada, 36, 1-10, 1979.

Stockner, J. G., Cliff, D. D., and Shortreed, K. R. S.: Phytoplankton of the Strait of Georgia, British Columbia, Journal of the Fisheries Research Board of Canada, 36, 657-666, 1979 .

Stockner, J. G., Cliff, D.D., and Buchanan, D. B.: Phytoplankton production and distribution in Howe Sound, British Columbia: a coastal marine embayment-fjord under stress, Journal of the Fisheries Research Board of Canada, 34, 907-917, 1977.

Tada, K., Morishita, M., Hamada, K.-I., Montani, S., and Yamada, M.: Standing Stock and Production Rate of Phytoplankton and a Red Tide Outbreak in a Heavily Eutrophic Embayment, Dokai Bay, Japan, Marine Pollution Bulletin, 42, 1177-1186, 2001.

Taguchi, S., Iseki, K., and Kawamura, T.: The estimate of annual production by phytoplankton in Akkeshi Bay, Japan, Journal of the Oceanographical Society of Japan, 33, 97-102, 1977.

Thayer, G. W.: Phytoplankton production and factors influencing production in the shallow estuaries near Beaufort, North Carolina, Ph.D., Department of Zoology, North Carolina State University, Raleigh, 170 pp., 1969.

Thayer, G. W.: Phytoplankton production and the distribution of nutrients in a shallow unstratified estuarine system near Beaufort, N.C, Chesapeake Science, 12, 240-253, 1971.

Therriault, J. C., and Levasseur, M.: Control of phytoplankton production in the Lower St. Lawrence Estuary: light and freshwater runoff, Naturaliste Canadien, 112, 77-96, 1985.

Thomas, J. P.: Influence of the Altamaha River on primary production beyond the mouth of the river, M.Sc. Thesis, University of Georgia, Athens, 1966.

Thompson, P. A.: Spatial and Temporal Patterns of Factors Influencing Phytoplankton in a Salt Wedge Estuary, the Swan River, Western Australia, Estuaries, 21, 801-817, 1998.

Tillman, U., Hesse, K.-J., and Colijn, F.: Planktonic primary production in the German Wadden Sea, Journal of Plankton Research, 22, 1253-1276, 2000.

Tundisi, J., Tundisi, T. M., Kutner, M.B.: Plankton studies in a mangrove environment: VIII. Further investigations on primary production, standing-stock of phytoand zooplankton and some environmental factors, Int Rev Gestamen Hydrobiol., 58, 925-940, 1973. 
Turner, R. E., Woo, S. W., and Jitts, H. R.: Phytoplankton production in a turbid, temperate salt marsh estuary, Estuarine and Coastal Marine Science, 9, 603-613, 1979.

Umani, S. F., Del Negro, P., Larato, C., De Vittor, C., Cabrini, M., Celio, M., Falconi, C., Tamberlich, F., and Azam, F.: Major inter-annual variations in microbial dynamics in the Gulf of Trieste (northern Adriatic Sea) and their ecosystem implications, Aquatic Microbial Ecology, 46, 163-175, 2007.

Van Spaendonk, J. C. M., Kromkamp, J. C., and De Visscher, P. R. M.: Primary production of phytoplankton in a turbid coastal plain estuary, the Westerschelde (the Netherlands), Netherlands Journal of Sea Research, 31, 267-279, 1993.

Vatova, A.: Primary Production in the High Venice Lagoon, Journal du Conseil, 26, 148-155, 10.1093/icesjms/26.2.148, 1961.

Vegter, F., and de Visscher, P. R. M.: Phytoplankton primary production in brackish Lake Grevelingen (SW Netherlands) during 1976-1981, Netherlands Journal of Sea Research, 18, 246-259, 1984.

Vegter, F., and De Visscher, P.: Nutrients and phytoplankton primary production in the marine tidal Oosterschelde estuary (The Netherlands), Aquatic Ecology, 21, 149-158, 10.1007/bf02255440, 1987.

Wafar, M. V. M., Le Corre, P., and Birrien, J. L.: Nutrients and primary production in permanently well-mixed temperate coastal waters, Estuarine, Coastal and Shelf Science, 17, 431-446, Doi: 10.1016/0272-7714(83)90128-2, 1983.

Wassman, P., and Aadnesen, A.: Hydrography, nutrients, suspended organic matter, and primary production in a shallow fjord system on the west coast of Norway, Sarsia, 69, 139-153, 1984.

Wassman, P., Naas, K. E., and Johannessen, P. J.: Annual supply and loss of particulate organic carbon in Nordasvannet, a eutrophic, land -locked fjord in western Norway, Rapport et Proces-Verbaux des Reunions Conseil Permanent International pour l'Exploration de la Mer, 186, 423-431, 1986.

Welschmeyer, N. A., and Lorenzen, C. J.: Chlorophyll budgets: Zooplankton grazing and phytoplankton growth in a temperate fjord and the Central Pacific gyres, Limnology and Oceanography, 30, 1-21, 1985.

Welsh, B. L., Whitlach, R. B., and Bohlen, W. F.: Relationship between physical characteristics and organic carbon sources as a basis for comparing estuaries in southern New England, in: Estuarine Comparisons, edited by: Kennedy, V. S., Academic Press, New York, 53-67, 1982.

Wetsteyn, L. P. M. J., and Kromkamp, J. C.: Turbidity, nutrients and phytoplankton primary production in the Oosterschelde (The Netherlands) before, during and after a large-scale coastal engineering project (1980-1990), Hydrobiologia, 282-283, 61-78, 10.1007/bf00024622, 1994. 
Williams, R. B.: Annual phytoplanktonic production in a system of shallow temperate estuaries, in: Some Contemporary Studies in Marine Science, edited by: Barnes, H., and George Allen, Unwin Ltd., London, 699-716, 1966.

Williams, R. B., and Murdoch, M. B.: Phytoplankton Production and Chlorophyll Concentration in the Beaufort Channel, North Carolina, Limnology and Oceanography, 11, 73-82, 1966.

Winter, D. F., Banse, K., and Anderson, G. C.: The Dynamics of Phytoplankton Blooms in Puget Sound, a Fjord in the Northwestern United States, Marine Biology, 29, 139-176, 1975.

Wium-Anderson, S.: Plankton Primary Production in a tropical mangrove bay at the south-west coast of Thailand, Ophelia International Journal of Marine Biology, $18,53-60,1979$.

Wood, B. J. B., Tett, P. B., and Edwards, A.: An Introduction to the Phytoplankton, Primary Production and Relevant Hydrography of Loch Etive, Journal of Ecology, $61,569-585,1973$.

Yamaguchi, M., and Imai, I.: Size fractioned phytoplankton biomass and primary productivity in Osaka Bay, eastern Seto Inland Sea, Japan, Bull Nansei Natl Fish Res Inst 29, 59-73, 1996.

Yamaguchi, Y., Satoh, H., and Aruga, Y.: Seasonal Changes of Organic Carbon and Nitrogen Production by Phytoplankton in the Estuary of River Tamagawa, Marine Pollution Bulletin, 23, 723-725, 1991.

Yokouchi, K., Tsuda, A., Kuwata, A., Kasai, H., Ichikawa, T., Hirota, Y., Adachi, K., Asanuma, I., and Ishida, H.: Simulated in situ measurements of primary production in Japanese waters. In Global Climate Change and Response of Carbon Cycle in the Equatorial Pacific and Indian Oceans and Adjacent Landmasses, edited by: Kawahata, K., and Awaya, Y., Elsevier, Amsterdam., pp. 65-88, 2007.

Zoppini, A., Pettine, M., Totti, C., Puddu, A., Artegiani, A., and Pagnotta, R.: Nutrients, standing crop and primary production in western coastal waters of the Adriatic Sea, Estuarine and Coastal and Shelf Science, 41, 493-513, 1995. 